\title{
An Analysis of Kanthapura by Raja Rao: A Postcolonial Study
}

\section{Bisma Butt}

Lecturer, University of Lahore, Chenab Campus, bisma.butt@ell.uol.edu.pk

\section{Asma Iqbal Kiyani}

Assistant professor, Mirpur University of Sciences \& Technology, Mirpur ,Asma.eng@must.edu.pk

\section{Naila Kanwal Dar}

MPhil Scholar, University of Lahore, Chenab Campus ,nailadar_grt@yahoo.com

\author{
Alia Asghar \\ MPhil Scholar, University of Lahore, Chenab Campus ,Aliaasghar396@gmail.com
}

\begin{abstract}
This study focuses the 'Kanthapura' to analyze the construction of historical consciousness in narratives and this fiction is used as literary aspect of nationalist ideology. Particularly, this work examines the political representation of women in Indian national movement in 1930 by using the theory of nationalism by Bhabha (1990). The study demystifies this novel to find out challenges of stereotypical Indian women and how they become solidified in the building process of Indian national identity. Kanthapura (Delhi Orient) is very much concerned to focus on the construction of Vedic Hindu ideal for women and the reason of writing true and authentic history to investigate the women's issues they face during the colonial period of India. The study sheds light on imagined and true nature of nationalist discourse and its effect on women in postcolonial India. It is not concerned with those doctrines of nationalist sentiments which are generalized through religious stereotypes rather it is paradoxical in nature that begins to assume identification with European accounts of India so it explores the idea of political desirability that shapes and constructs the ideology and as well as it allows for the presentation of unified identity of India.
\end{abstract}

\section{KEYWORDS:}

Philosophical depth, colonial, decolonization, nationalism

Article Received: 18 October 2020, Revised: 3 November 2020, Accepted: 24 December 2020

As Indian National movement has been faced much critique, one of them is Kanthapura by Raja Rao. This fiction is inspiring and meaningful in terms of true critique to highlight the ideological height and philosophical depth. For Rao, the representation of literature is spiritual and Sadhana. In this metaphysical comedy, Indian philosophy is presented through personal, contemporary, political and social life. The philosophical overtone used by Rao in this fiction can be easily understood by any reader having upanishaic orientation. The depiction of Indian villagers living in South is best modeled through metaphors and similes. A Brahmin widow, an ordinary woman belonging to a scholarly family is the narrator of this story. She is a figure of sympathy and native wisdom for all the people in the village. Rao symbolizes this grandmother with rich folk wisdom and puranic view point presenting her narrative by weaving the present with past and gods with the men together. Her puranic aspects of thinking make her pure and objective in her narrative of political movement. This fiction depicts the contemporary occasions having uproariousness. Kanthapura is instilled with spiritual motivation as to that of the Puranas. The purpose of this study is to highlight the nationalist discourse and its influence on women in postcolonial India. This study is not taking into consideration the religious and spiritual stereotypes but focusing on to explore the idea of political desirability shaping and constructing the ideology and demonstration of India as 'unified identity'.

Nationalism and its exposition in historical novel that helps to generate the struggle for freedom and women's actual role in it are actually diverged. The study demystifies this novel to find out challenges of stereotypical Indian women and how they become solidified in the building process of Indian national identity. 
This sort of literature is very important for historians for two reasons: First, to understand the nationalist historiography in form of obstinate essentialist representation, second, to undermine the postcolonial Indian intellectuals' development. This study explores the modified conception of nationalist ideology by exploring the women's issue in last years of colonial rule in India. Such type of political prudence shapes the ideological constructions. The text that has been chosen is Kanthapura by Rao (1938) in which Kanthapura is a fictionalized village.

The tale of village folk is narrated through 'harikatha' medium by a grandmother. She recalls the Mahatma Ganghi's surge of nationalism that how he surpassed the differences and revolutionized the villagers into freedom fighters. It is obvious from the name of the novel Kanthapura that Rao wants to write a heroic history where men and gods are united. The legendary flavor recounted to independence struggle is established in beginning as the writer of the novel recognizes them as Indian.

Novel is tied up with nationalism; the text is politically motivated by oppressive and resistant tensions of the era. The purpose of describing all these is not to provide context but to analyze the writer's work. Rao is very much particular in encoding the conditions which prompt the need for nationalist sentiment. To arouse the people and shaping the historical consciousness, this novel must be taken as genre of historical fiction which was emerged at that time in India. Obviuosly, Kanthapura is leading light in his genre, stretches the naivety of readers, it is credible for the freedom struggle circumstances where the desire is to get back his past and it recounts the flexibility for the acceptance of mythical and legendary history. Other than the political circumstances, the preceding traditions of narrative-puranic-contributes the situating narratives remote in time.

The leading feature in such works is not so much consistent with the domain of reality because of its functionality is constituted by glorified vision of India. This explains the extremely personalized view of Mahatma Gandhi because the main focus is on man as compared to movement.

The literary devices which are used in this novel asserts a committed Indian village model that allows to present it as homogeneous, unified, an identity that held stupendous call for intellectuals in the 1930s. Gandhi's pinnacle into embodiment further contemporary politics into religious saga was an effort to develop a popular national movement in a society markedly divided by cast, class and language. The most important task within colonial domination was to present the country's unitary identity. Consequently, this novel is mapped within identity confining the nation.

The production of nationalist ideology in particular narratives and its capacity of attempting to absorb no of people through its rehtoric is remarkable. within the colonial situation, the figuration of a common identity does lead to unitary nationalism for it is only through collective religious or linguistic sentiments that political ends can be reached (Sethi, 1996, p.2). When there is a desire to dominate, they motivate the strategies such as exercising of particular social group's ethnic superiority. Forexample, the rhetoric of Indian's nationalism is always exercised by brahminic superiority and Hindu iconography since Hindus have majority and with the course of this study, the use-value of Vedic Hinduism in the creation of its women will be observed.

To understand the model of cultural identity by Rao, it is essential to locate the women of the novel in movement of freedom. Equally, as the novel focuses on Nationalism of Gandhi, it is important to see the role of women shaped by Gandhi's auspices within nationalist agenda. Now, here the argument is developed that Gangi's nationalism and after this, Rao presents the women in traditional and standard roles, which did not allow them complete liberation. Keeping in view both the factors, historical and fictional, this study will reveal two important facts: first, fictional qualities of historical movement, second, deviation of the writer from the actual point or the 
document. These two facts make this study possible to comment on the nationalism's imagined nature.

The context of the novel reveals the contradiction between women's desire and their participation' permitted sphere in national movement and this depicts the movement of ideology but to some extent it is opposed to its action. Therefore, it is better to analyze it with the help of two models: ideological and novelistic but it will be observed with the development of novel that author is connected with the former model and the inherent features of novelistic form can be operated to explain the latter model. Participation of women can be observed in wider theme of unrest peasant. Gandhi involved women in independence movement and this fact offers contrasts and comparisons with the fictional heroines of Rao. In Kanthapura, the patriarchy of Brahmin's domination is clear but it is surprising in the novel that both the Brahmin and non-Brahmin are equally permitted to participate in movement as males were involved equally in Gandhi's movement. Rao even went so far in narrating that they were allowed to assemble into 'Sevika Sangha'. Though such sort of dispute was unknown to Brahmin culture, they suffered silently the 'outrage'. Chauvinistic Brahmin culture was threatened by Gandhi's treatment of women to join the independence movement.

In different aspects, Gandhi's work was challenging to pre-existing patriarchal order and invoked a response in women because his protest had feminine nature which touched the domain of housekeeping where females were not allowed in male dominating society to exercise the formal power of taking positions. But by fasting and penance-Gandhi's protests' hallmark---they could push the men into acquiescence. This technique worked for Gandhi even when it was shifted to imperialists and followers were nonviolent specifically the role of women were being played pacifically.

According to Kumar (2018) Gandhi subverted the nature of struggle and its anti-imperialist effect by evoking the females for independence movement as they were passive resistant. So, in this way, Gandhi provides a moral effect to the emphasis of struggle with the help of female persistence. Although, he was criticized by his adversaries that his approach is effeminate that can cause a disablement, His approach towards resistance was very affective in evoking the women into national independence movement. So, Kumar (2018) describes this situation in this way that Gandhi used the power of self-sacrifice and pacifism not only to avoid the manly virtues but also to subvert the territory of masculinity and convert into morally strong.

As Gandhi advocated that women should have equal rights in all spheres, by asserting this he engaged all the women into non-violent struggle at social order. Moreover, $\mathrm{He}$ maintained that when females of a country woke up, no one can hamper Swaraj (Sethi, 1996). In this result, women's role came into spotlight not only for themselves but also for all other groups in society who were exploited against abuse, inequality and social injustice. National integration program of Gandhi worked for the betterment of all even for the 'harijans'-the untouchables and for the women also to change the track of the Indian society.

Although Gandhi stood against the discursive practices of widowhood, child marriage, tradition of 'devadasis', purdah, and the dowry but his approach towards the role for women was not broader as he remained limited to the domestic sphere and hardly could be seen outside the independence movement. Ahmed (1984, p. 9) sheds lights on the vision of Gandhi in this way that Gandhi believed that both men and women are necessary for the struggle but in different roles by suggesting an order -service to husband, family and then country. Moreover, he explained that serving to country can be done only when there is no compromise on first two services. He idealized Sita who stood for devotion, sacrifice and moral strength.

Sita is basically a representation of Indian society who broke the primitive stereotypical pattern of inferior woman within the traditional archetype. Gandhi asserted that females are not weak because 
they are full of moral strength which enables them to encounter the brutal physical strength of males (Sethi, 1996). It is obvious that Gandhi did not completely transformed the role of women or to visualize the revolution but on the other side his writings revealed the immobility of women within the system regardless of their inner strength and the moral strength he attributed to females are innate, genetic complexion that has little relation with humiliation, generations of exploitation and difficulties.

Although he worked for social reforms but he focused the symbology of mother so in this way he tried conveniently to maintain the connection with Mother Goddess and mother India. He presented the picture of woman as essential one, passive and unchanging entity which possesses freedom but their function confined within limited parameters (Kishwar, 1985).

Further, he extended the women's role in specific sphere of patriarchal system, he disintegrated the family resistance for their women and he ensured that women will come outside the house for struggle. It was Gandhi's strong beliefs that care for children and procreation is inconsistent with public service (Gandhi, 1927). He gave away his feelings for wealth and children and started to live a life of 'Brahmacharya' but he advocated the housekeeping preference for all women because it was impossible to service both domestic and public adequately.

Gandhi, in this way, harmonized the national movement and family duties in terms of women's role. Ahmad depicts the role of Gandhi in this situation as Gandhi's attitude for women's role in independence movement was often contradictory or it can be said on three levels.

Three levels are such as: First, the aged women and those who have family responsibilities e.g. to take care of their children, they had to only fulfill their responsibilities and these cannot be sacrificed for the sake of country. Second, if they were already married, they had to remain celibate for the sake of movement (Sethi, 1996) as he advised Vijaylakhshimi and her husband. Third, those women who were single at that time were advised to remain single for the struggle of independence. As he was always tried to save the traditional image of woman, he could not avoid disfiguring this model.

The level of participation and different circumstances dictated the Gandhi's role for woman but generally, he was much concerned for issues like 'swadeshi' and prohibition for the domain of woman as females were badly affected in this perspective. Women belong to all sectors faced the drinking of men, within the national movement, the toddy-picketing inclusion could gain momentum if it was turned over to woman. Apart from their degree of recruitment, their role was formed and defined within the movement of independence. Gandhi did not raise his voice for caste system and as well as for untouchability so therefore, he did not get clear aim to mobilize the women for independence movement but their involvement was a strategic tactic although the intention was not to empower them.

In Kanthapura, the politics of villagers cannot be simply limited to participation level as narrated in the novel. Although a divided Indian society can be summon into a peaceful society by political aspect offered by Rao, his status in Brahminic intelligentsia, together with interruption of his own interest in politics, has to be focused also. Similarly, three main female characters in Kanthapura that are Rangamma, Ratna and obviously Achakka, the grandmother-narrator, are Brahmin widows and come from place of society that is took into account by author. Women in village thought about Rangamma and Ratna that they are natural and great leaders.

Rangamma and Ratna were having husbands earlier, so they are not having a complete control over their sexuality, even in current moment of narration, they are having status of widows. So marriage have a societal control most prominently over female sexuality, is not wholly to be dispensed with. Married women can succeed as Nation members, and cannot be physically sterile as they can if remain unmarried. Both Rangamma as well as Ratna are thought to be mother figures by remaining in the text; for Moorthy after his 
mother's death, Rangamma behaved as surrogate mother; Ratna also shows regard for the fasting hero. However it should be noticed that both of them belong to such cast in which women especially widows are always restricted severely. They are said to fulfil their main duties first, nevertheless insofar as their national movement as followers of the Sevika Sangha hits with national delight.

'If we are to help others, we must begin with our husbands,' and Rangamma tells Satamma that, 'your husband is not against Sevika Sangha. He only wants to eat in time...' Rangamma ask her to cook regularly, in addition we all say, 'we should do our duty. If not, it is no use belonging to Gandhi group.' Rangamma says that, 'That is right, sister,' and we say that, 'we shall not forget our children and our husbands' (Rao, 1938).

In 'Protection' of female within home, Rao thinking is same as that of Gandhi beliefs. Gandhi had spoken the same thing in a speech at conference of textile workers in Ahmedabad.

It is our responsibility to look for those workers who send their wives as well as their children to do work in factories and to stop them...asking children to do work is not right as it is not for them. And it is also not for women that they should work in factories. They have to do a lot of work in their homes. They should take care of their children; they can also make their husband feel in peace when he turns back home exhausted, minister to him, make him happy if he is angry and can do many other work by staying at home...who will manage our social and home work if we let them to go to factories? It will destroy our social life and decay our moral values if we send women to do work...I am agreed that it will result in fall if both men as well as women go for work. So don't send women for work; protect your respect; no one will cast a wicked eye on them only if you are having manliness.

Exaggerated by his own middle class malecontrolled attitudes, Gandhi stresses upon that women should remain in homes rehearsal their spinning in its limits when came to know issues related to respect and fidelity. As Sujata Patel has described, the oath of swadeshi is converted from political reinforcements to moralistic and religious problems and caught protection of Indian women as dhanna. Return to defense of this respect, becomes as Ishwarbhakhti or dedication to God (Mondal, 1999).

Rangamma casted vote as a representative because 'the congress is for the weak and the lowly' (Rao, 1938). Gandhi's thinking about second group of females, are also merged in lives of both Rangamma and Ratna that is to be nationalistic and celibate additionally. Women regulate best with Gandhian system, since neither woman has a kid or spouse. Similarly like Gandhi, Rao also makes categories for women, first category is of those who serve at home and second who do not bother responsibility of home and work for nation. It may mean that Rao kept the honored position of marriage and women's part as a dedicated wife, and sacrificing mother from earliest models of higher caste Hindu women which adapt to the current urban, middle-class Hindu society. Only this class of women can frequently respond to the image of Sita who left her luxurious life style for her husband, Rama, into exile when he was ejected from his empire by self-seeking step mother. While in other aspect, current society of India was full of those women who could not pay for sari, clothes or jewellary. Currently many women in Indian society were not able to meet their basic needs even a sari, clothes or jewelry. They had no option instead of wearing cheap handlooms until they did not carry spin and wear khadi. For this an ideological preference is shown for the middle-class urban women by both Gandhi and Rao. The grandmother's story gives us juncture to hear the women's voices outside the limits where they are not supposed to be scene.

But how can we be like we used to be? Now we hear this story and that story, and we say we too shall organize a foreign-cloth boycott like at Sholapur, we too, shall go picketing cigarette shops and toddy shops, and we say our Kanthapura, too, shall fight for the Mother, and we always see the picture of Rani Lakshmi Bai that Rangamma has on the verandah wall, a 
queen, sweet and young and bejeweled, riding a white horse and looking out across the narrow river and the hills to where the English armies stand (Rao, 1938)

It may be described as opposing feminist courage as a model of female, Rani Lakshmi Bai of Jhansi was murdered in the starting of 1857 , it is valiant till now. Therefore, she can stand for tradition, thus diffuse with modernity. It realizes that the women should not be treated like this, as they are treated.

The views and ambitions of Achakka are a dispute for feminine identity construction inside home, advocated by Gandhi and absorbed by Rao. For being an oral storyteller the grandmother separates herself and supposes the character's attribute which is not able to do what Rangamma advocates, now the difference of dramatic and nationalistic levels of stories is clear. As Lakshmi Bai, in opposition, for the service of the nation she tries to devote herself. Gandhi had supported feminist struggle at one side, on other side he would have a concurrent address involvement at two related levels: one ideological and other a more material daily-life level (Mohanty, Russo \& Torres, 1991). Achakka takes many complex home belongings, feels herself as Rani Bai, and is influenced by Shakti (Nandy, 1980).

The female point of view is supposed to be more significant at Shakti level than Rao. When the women suppose their designation with village protectors' power, the women-power turns the Kenchamma into goddess. Kenchamma's achievements, that the village pays to its very beginning and her life story is used for refraining the event's methods that affect villager's lives. Women believe the presence of Kenchamma in everyone for more motivation. Actually for their unnatural valour they became frighten and everyone becomes Kenchamma:"we felt as though we had walked the holy fire" (Roa, 1938).

Kenchamma is believed to have "even settled down among [them]" (Roa, 1938), and that's the reason Kenchamma killed demon. Thus, the liberation of their possible strength, Kenchamma as a women role creates a new concept in novel and being realized in the village. These stories for women to women show the growing power of women.

Rao dose not only says the women to consist his readership. To increase the "perlocutionary effect" on both genders the distribution of audience as female can be a way for attracting them (Sethi, 1996). To gather the listeners the availability of the story to female listeners may suggest Rao's investing as a seductive appeal of "voyeurism". As men are omitted in audience of females gathering in text, so there is no restriction for their presence during its reading. In that connection the story not only widnes the duration of the story among all audience and also enhance a new starting among women.

In India, the woman's fear is linked with matriarchal society where goddesses as compared to gods are considered on first place, so these are the domains only where woman's rule or in other words 'stri-rajya' is dominant which is totally against the braminic system that imposes restriction on woman's sex. Kanthapura's action supports this power of matriarchy in form of Achakka and that is why a conflict can be seen between her narration and the dictum of Rangamma. Achakka is the representation of dominant matriarchy and shows resistance to rigid labor's division of sexes so she is very much active in national movement just like other women of Ashram who spur the Gandhi to let them join the 'Dandi' march along with men whereas Rangamma does not play a role for any fundamental change in woman's traditional role.

Although Gandhi had seen the courage and eagerness in them but he refused them by giving an ambiguous reason that they even play their role effectively in national movement by avoiding breaking the salt laws (Andrews, 1930). In the novel, the awakening 'shakti' is dropped off when Kenchamma- goddess takes over from Kenchamma-the woman. Gandhi's vision regarding the role of woman to remain associated with housekeeping urge them within plodded existence, therefore, Rao also cares about the picture of woman in the novel so that the 
traditional woman's presentation would remain same and as well as he freezes the woman of the third world in space, time and history. Mohanty, Russo and Torres (1991) depict this situation as it was only middle-class men who recognize the emergence of women of India in national movement.

In this novel, at Skeffington coffee estate, the peasant women were present but this book does not address these women. Although the earning of peasant women was very small as compared to men and moreover they were living in sexual exploitation's fear, it was the effort of Brahmin's women that 'Sevika Sangha'was formed. Association for national purposes exists at any rate; anyhow, the parallels are there for Nizam's feudal oppression and Hindu landlords in Hyderabad (Telengana) in 1948-1951 (Sethi, 1989).

Telengana peasants were facing forced labor and taxes in the form of feudal exploitation and for women, this exploitation comprised of sexual assaults and 'adibapa' - a girl used to go with the bride to her husband's home and then she had to face the sexual gratification along with other services. But afterwards, the women started to resist for the sake of better wages, land, reasonable interest on grain loans and cash and as well as on fair rent. This awareness provides a striking contrast to this novel in which agitation is suppressed and hierarchies are dissolved. It is surprising that Kanthapura depicts anti-toddy campaign but no specific base for women's experience justifiable to agitation. Rao keeps the story away from the real villagers' experience by focusing only on Gandhi's philosophy of religion. Women are not allowed to give up the nationalism to let them free of their suppression but the national movement shows them a new direction 'a great independence', for them it was Swaraj. At the end of the novel, it can be heard that 'Men will come from the city, after all, to protect us!" (Rao, 1938).

Telengana revolt is considered as best period for the women but it was revealed that their vision was denounced because they were consistently judged and weighed up within their private housekeeping abilities (Kannabiran \& Lalitha, 1989). The hegemonic project of nationalism can be viewed as women of the new middle class in $19^{\text {th }}$ century of India became active participant in national movement-complicit in the framing of its hegemonic strategies as much as they were resistant to them (Chatterjee, 1994). The most important concern here is that how women were imagined and conceptualized in national movement. In Gandhi's independence movement, they got the direction first time and it is also true those social regeneration goals of his confused attitudes were no far but it was national struggle that urges him to mobilize the women. Rao uses the similar tactics to provide same representation by connecting the women with national movement but this sentiment was not connected with their social consciousness. Throughout the novel, their ideologies remain in conflict with feudal assumptions which give them meaning culturally and restrict them socially. Rao confined the traditions of culture within which fabulation is understood and his work is remarkable by constructing the belief i.e. mythological features of Indian 'soul'.

Bibliographgy

[1] Ahmed, K. G. (1984). Women's Role and the Freedom Movement' Occasional Paper. Nehru Memorial Museum and Library, New Delhi.

[2] Andrews, C. F. (1930). Mahatma Gandhi's Ideas: Including Selections from His Writings (Vol. 10). Macmillan.

[3] Ashcroft, B., Griffiths, G., \& Tiffin, H. (1989). Theory at the Crossroads: Indigenous Theory and Post-colonial Reading. The Empire Writes Back: Theory and Practice in Post-Colonial Literatures. London: Routledge.

[4] Beya, B. (2012). Abdennebi. Mimicry, Ambivalence and Hybridity. Postcolonial Studies at Emory.

[5] Bhabha, H. K. (1994). The Location of Culture London: Routledge. 
[6] Dalton, A. M. (2007). The Contribution of Ziauddin Sardar's Work to the ReligionScience Conversation. World Futures, 63(8), 599-610.

[7] Filmmakers. Ed. Janis Cole and Holly Dale. Kingston: Quarry, 143-55.

[8] Hallward, P. (2001). Absolutely postcolonial: Writing between the singular and the specific. Manchester University Press.

[9] Huddart, D. (2005). Homi K. Bhabha. Psychology Press.

[10] Kanthapura(1938). New Delhi : Orient Paperbacks, 1970.

[11] Kishwar, M. (1985). Gandhi on women. Economic and Political Weekly, 1691-1702.

[12] Kumar, P. K. (2018). Images of India in the select novels of Salman Rushdie.

[13] Mohanty, C. T., Russo, A., \& Torres, L. (Eds.). (1991). Third world women and the politics of feminism. Indiana University Press.

[14] Mondal, A. (1999). The Ideology of Space in Raja Rao's Kanthapura. The Journal of Commonwealth Literature, 34(1), 103-114.

[15] Nair, M., Cole, J., \& Dale, H. (1993). Mira Nair. Calling the Shots: Profiles of Women Parsons, J. B., \& Harding, K. J. (2011). Post Colonial Theory and Action Research. Online Submission, 2(2), 1-6.

[16] Nandy, A. (2007). The lure of 'Normal' Politics: Gandhi and the battle for popular culture of politics in India. South Asian Popular Culture, 5(2), 167-178.

[17] Narasimhaiah, C. D. (1973). Raja Rao. New Delhi: Arnold-Heinemann India.

[18] Sethi, R. (1996). Contesting identities: Involvement and resistance of women in the Indian national movement. Journal of Gender Studies, 5(3), 305-315.

[19] Srinivasa Iyengar, K. R. (1989). Indian writing in English. Sterling Publishers Private Limited. 